University of Nebraska - Lincoln

DigitalCommons@University of Nebraska - Lincoln

Textile Society of America Symposium

Proceedings

Textile Society of America

2020

Camelid Fleece and the Hidden Histories of Colors in the Andes

Penelope Dransart

Follow this and additional works at: https://digitalcommons.unl.edu/tsaconf

Part of the Art and Materials Conservation Commons, Art Practice Commons, Fashion Design Commons, Fiber, Textile, and Weaving Arts Commons, Fine Arts Commons, and the Museum Studies Commons

This Article is brought to you for free and open access by the Textile Society of America at DigitalCommons@University of Nebraska - Lincoln. It has been accepted for inclusion in Textile Society of America Symposium Proceedings by an authorized administrator of DigitalCommons@University of Nebraska - Lincoln. 


\section{Camelid Fleece and the Hidden Histories of Colors in the Andes} Penelope Dransart ${ }^{1}$

In this article, I explore hidden histories of vicuñas, alpacas, guanacos and llamas collectively known as South American camelids - from the perspective of their fleece. Camelid fleece is notable for its warmth. Its fibers, moreover, possess qualities such as resilience and elasticity. In alpacas and llamas, they can be long and fine, in addition to which they have desirable light reflecting qualities. As a result, camelid fleece is an example of a protein fiber suitable for dyeing to produce particularly vibrant hues, making it an important resource for spinners and weavers.

Alpacas and llamas, which are the domestic forms of camelid, nowadays may be white, beige, tan, brown, reddish-brown, grey or black, or a combination of these tones. Did the present-day range of possibilities exist in the past? Perhaps the currently existing variation has been the outcome of a long process? These questions lead me to ask how textile workers might have exploited natural fleece shades as a complementary resource along with dyed yarns. Did the requirements of weavers for certain types of fleece for specific needs encourage herders to breed alpacas and llamas in an attempt to provide sufficient quantities of animals with the desired fleece characteristics?

Using direct evidence provided by ancient textiles and indirect evidence furnished by depictions of camelids in ceramics, I investigate how dyers, spinners, and weavers used camelid fleece in order to meet culturally specific requirements. My main focus is on the second half of the first millennium of the common era when two states, Tiwanaku and Wari, rose to prominence in the Andes. ${ }^{2}$ The fleece characteristics of the llamas and alpacas herded in these societies was the outcome of a long process, aspects of which can be traced back through the archaeological record.

The earliest evidence for the domestication of alpacas from 6500 years ago has been reported from the Puna de Junín in the Central Andes. ${ }^{3}$ What the fleece was like of these earliest domesticates is unknown because the seasonally moist environmental conditions do not favour the preservation of organic remains other than animal bones. In the South-Central Andes, evidence indicates that, from 4400 years ago, people in the Atacama Desert were beginning to herd llamas to complement the hunting of wild vicuña and guanaco. ${ }^{4}$ Arid conditions in this more southerly area permit fragile fleece remains to survive.

\footnotetext{
${ }^{1}$ Honorary Reader, Department of Social Science, University of Aberdeen.

${ }^{2}$ Margaret Young-Sánchez (ed.), Tiwanaku: Ancestors of the Inka, Lincoln, Nebraska: Denver Art Museum and University of Nebraska Press, 2004; Susan E. Bergh, (ed.), Wari: Lords of the Ancient Andes, New York: The Cleveland Museum of Art and Thames and Hudson, 2012.

${ }^{3}$ Jane C. Wheeler, "On the Origin and Early Development of Camelid Pastoralism in the Andes." In Animals and Archaeology: 3 Early Herders and Their Flocks, edited by J. Clutton-Brock and C. Grigson, 395-410. Oxford: BAR International Series 202, 1984.

${ }^{4}$ Guillermo L. Mengoni Goñalons and Hugo D. Yacobaccio, "The Domestication of South American Camelids: A View from the South-Central Andes." In Documenting Domestication: New Genetic and Archaeological Paradigms, edited by Melinda Z. Zeder, Daniel G. Bradley, Eve Emshwiller, and Bruce D. Smith, $228-244$. Berkeley: University of California Press, 2006.
} 


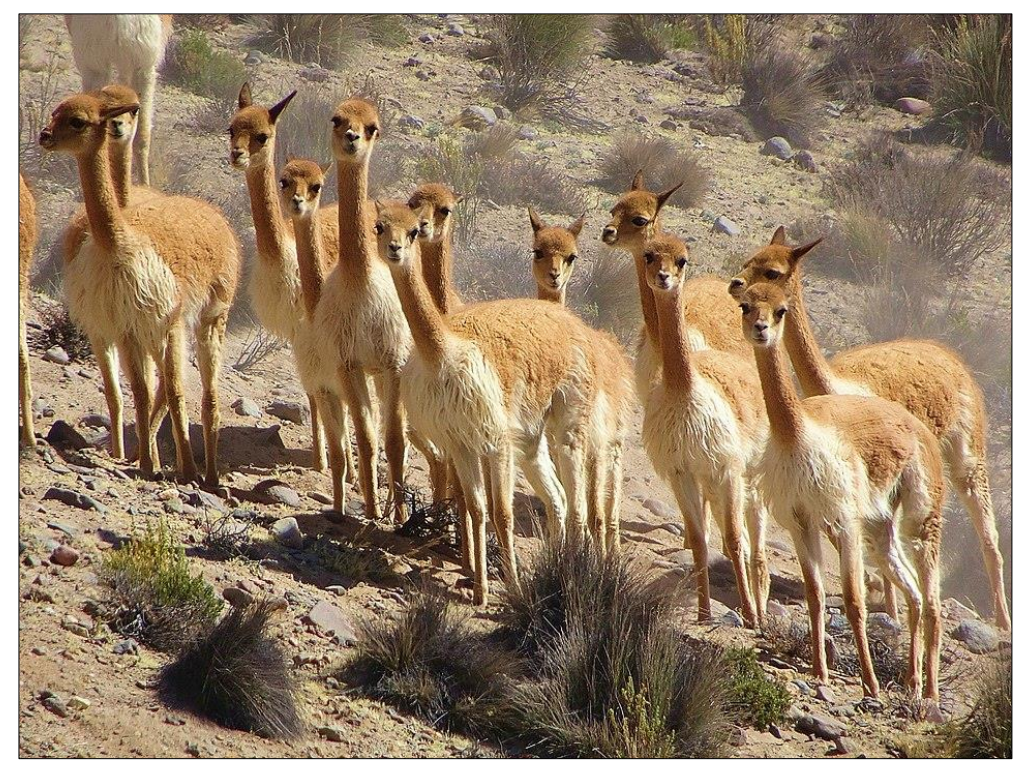

Figure 1. Vicugna vicugna mensalis (Thomas 1917) photographed on the road between Arequipa and Puno, Peru.

Marshallhenrie, CC BY-SA 4.0 <https://creativecommons.org/licenses/by-sa/4.0>, via Wikimedia Commons

Two subspecies of vicuña are known: Vicugna vicugna mensalis (Thomas 1917) and Vicugna vicugna vicugna (Molina 1782), the latter being found in the Atacama region. The uppermost parts of the body of V.v. mensalis are characteristically dark cinnamon in hue, while the lower part of the face, the belly, inner legs and ventral part of the tail are white. These vicunas sport a prominent white bib of hair. V.v. vicugna, in contrast, lacks the white bib and the upper parts of the body are lighter beige in hue. The proportion of white on the body is more extensive than in the northern subspecies. ${ }^{5}$ Guanaco fleece is somewhat similar in color, but the upper part of the animal's face is grey, making it distinctive from vicuñas.

Some of the unspun fleece samples and yarns found on archaeological sites in the quebradas descending from the highlands to the east of the Salar de Atacama are likely to have been obtained from hunted vicuña and guanaco. A large quantity of yarns and unspun fleece excavated from midden deposits at the site of Tulan 54 displayed a range of fleece colors similar to that of the wild camelids. The site is dated to about 3000 years ago. It would seem that the llamas being raised in the quebrada at that stage had similar coats to their wild counterparts, whether guanaco or V.v. vicugna. Only two samples differed - a small piece of unspun black fleece and a yarn spun from a fleece darker in brown than the more numerous examples of white, beige and tawny colours. ${ }^{6}$

Tulan 54 spinners selected fibres carefully for dyeing. They used the yarns either for the value of their natural fleece color or for dyeing. The yarns chosen for dyeing were the beige or tawny colors from the flanks and back of the vicuñas, guanacos or llamas. White was preserved for its brilliance and no cases of white yarns were found to have been dyed. ${ }^{7}$

\footnotetext{
${ }^{5}$ Jane C. Wheeler and Jerry Laker, "The Vicuña in the Andean Altiplano," The Vicuña: The Theory and Practice of Community-Based Wildlife Management, edited by Iain J. Gordon, 21-33. New York: Springer, 2009.

${ }^{6}$ Penelope Z. Dransart, Earth, Water, Fleece and Fabric: An Ethnography and Archaeology of Andean Camelid Herding, London: Routledge, 2002.

${ }^{7}$ Dransart, Earth, Water, Fleece and Fabric, 213.
} 
Jan Wouters analysed two of the yarns from Tulan 54, reporting the presence of purpurin, indicating that the dye would have been obtained from the roots of a Relbunium species. ${ }^{8}$ The practice of dyeing yarns red already had antecedents in the Archaic Period of the region, because excavation on the earlier hunter-gatherer site of Tulan 52 yielded yarn of a faded red colour. ${ }^{9}$ The earliest reported dyestuff in the Andes, however, is indigotin, found in two textiles twined from cotton yarns from the Central Andean site of Huaca Prieta. The textiles came from a deposit dated to c. 6000 years ago. ${ }^{10}$

Recent systematic studies analysing dyes indicate that the use of the plant genera Relbunium and Galium (which contain purpurin and other anthraquinones) was ubiquitous in early dyed textiles in both the Central and the South-Central Andes. By about AD 500, the use of the cochineal insect was becoming available as a source of red, appearing in late Nasca textiles. Nathalie Boucherie and her colleagues observed that cochineal was combined with a plantbased source to produce red in Nasca textiles. ${ }^{11}$ Thereafter, in the Central Andes, a trajectory occurred in which cochineal came to displace Relbunium, but the use of plant sources of red dyestuffs continued in at least parts of the South-Central Andes, as reported, for example, in
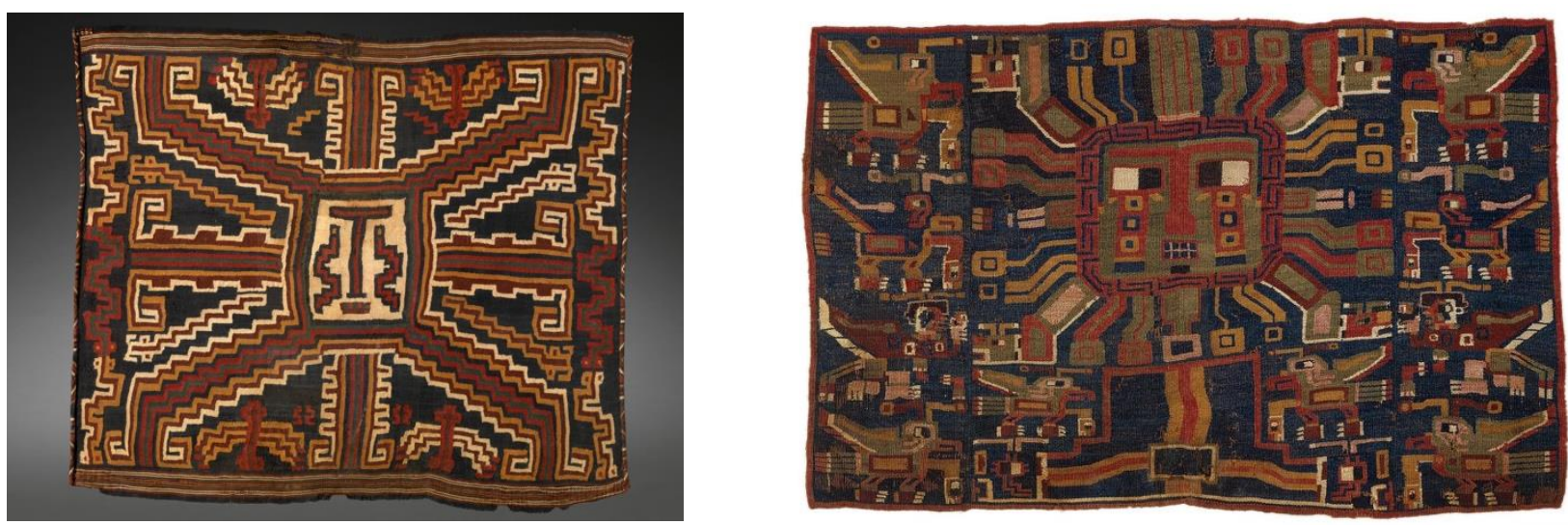

Figure 2. Siguas 1 style panel. Camelid fibre, discontinuous interlocking warp and weft. Paul and Dora Janssen-Arts Collection MAS.IB.2010.017.273 Photograph @ MAS Museum aan der Stroom, Antwerp www.mas.be

Figure 3. Pukara or Early Tiwanaku style shoulder panel from a tunic. Camelid warp (paired) and weft, interlocked tapestry. 1994.203 Photograph (C) Museum of Fine Arts, Boston www.mfa.org

San Pedro de Atacama. ${ }^{12}$ During the period when Tiwanaku and Wari textiles were woven, dyers had recourse to both plant- and insect-based sources of red. ${ }^{13}$ Not only might dyers

\footnotetext{
${ }^{8}$ Dransart, Earth, Water, Fleece and Fabric, 213-214.

${ }^{9}$ Dransart, Earth, Water, Fleece and Fabric, 206.

${ }^{10}$ Jeffrey C. Splitstoser, Tom D. Dillehay, Jan Wouters, and Ana Claro, "Early Pre-Hispanic Use of Indigo Blue in Peru," Science Advances 2(9) (2016): e1501623.

${ }^{11}$ Nathalie Boucherie, Witold Nowik, and Dominique Cardon, "La producción tintórea Nasca: nuevos datos analíticos obtenidos sobre textiles recientemente descubiertos en excavaciones," Nuevo Mundo Mundos Nuevos Colloques, 2016. http://journals.openedition.org/nuevomundo/69222

${ }^{12}$ Hermann N. Niemeyer and Carolina Agüero, "Dyes Use in Pre-Hispanic Textiles from the Middle and Late Intermediate Periods of San Pedro de Atacama (Northern Chile): New Insights into Patterns of Exchange and Mobility," Journal of Archaeological Science 57 (2015): 14-23.

${ }^{13}$ Jan Wouters and Neomi Rosario-Chirinos, "Dye Analysis of Pre-Columbian Peruvian Textiles with HighPerformance Liquid Chromatography and Diode-Array Detection," Journal of the American Institute for Conservation 31(2) (1992): 237-255.
} 
combine Relbunium and cochineal to produce a specific red, they also combined luteolin-like dyestuffs, which yield yellows, with Relbunium. ${ }^{14}$ Tiwanaku dyers had particular expertise in golden colors, which were, perhaps, inherited from the earlier Siguas and Pukara textile traditions in the development of a particular iconographic tradition focusing on a rayed head (Figures 2 and 3). ${ }^{15}$ For dyeing yellows, Tiwanaku dyers must have taken into account the natural colors of the fleece as best suited for the hue they wished to achieve. For the finest of their textiles, they would have been able to select the fleece of either V.v. mensalis or V.v. vicugna, whereas only the former would have been easily available to Wari dyers.

As a political entity, Tiwanaku, south of Lake Titicaca, Bolivia, expanded from the site of the same name to exert political, economic, and religious control in the South-Central Andes between c.400 and c.1000. Similarly, Wari, north of Ayacucho, Peru, came to power in the Central Andes c.550-c.900. These two states originated in the Andean highlands and expanded to control inter-Andean valleys and coastal zones: Tiwanaku in the South-Central Andes and Wari in the Central Andes. The division between these two regions extends westward from the Nudo de Vilcanota in Peru, between the Sihuas and Tambo Rivers. This contact zone seems to have been one of the places where efforts were made to increase the availability of white fleece.

A highly unusual find of twenty-six alpacas and llamas at the site of El Yaral, at the southwestern extremity of the Moquegua valley in the far south of Peru, consisted of animals naturally mummified by the prevailing aridity of the environment. The site is assigned to the Chiribaya tradition, dating from the Late Intermediate Period (AD c.950-c.1350). Jane Wheeler and her colleagues took samples from the coats of some of these animals. They identified four different fiber types in the coats: extra fine fiber and fine fiber alpacas, fine fiber llamas, and coarse fiber llamas. ${ }^{16}$ Not only are three of these types finer than those of contemporary llamas and alpacas, the animals also displayed greater uniformity in both fiber diameter and coloration. One of the llamas, the individual that was found to have a coarse fiber, and one of the alpacas were multicolored. The other alpacas sampled for the study included one with all-white fleece, two with red-brown fleece and two with grey-beige fleece. ${ }^{17}$ El Yaral was occupied at a time when Wari dominance had ceased and that of Tiwanaku was ending. It nevertheless provides an insight into the sort of fleece types to which the spinners and weavers of these two earlier traditions are likely to have had access.

According to Jane Wheeler, Lounès Chikhi, and Michael W. Bruford, 90 percent of Peruvian produced alpaca fiber now measures more than $25 \mu \mathrm{m}$ in diameter, compared with $17-22 \mu \mathrm{m}$ in pre-Hispanic animals. ${ }^{18}$ In the past, therefore, spinners and weavers counted on having different qualities of fleece at their disposal. While this factor makes it difficult to identify whether fine yarns in pre-Hispanic textiles were spun from the fleece of vicuña, alpaca or

\footnotetext{
${ }^{14}$ Wouters and Rosario-Chirinos, "Dye analysis," 252.

${ }^{15}$ Haeberli, Joerg, "Siguas 1: a newly identified Early Horizon culture, Department of Arequipa, Peru." Textile Society of America Symposium Proceedings, Paper 392, 2002.

https://digitalcommons.unl.edu/tsaconf/392; Rosoff, Nancy B., "The Rayed Head and Stepped Platform: A Core Symbol of the Southern Andean Iconographic Series," Textile Society of America Symposium

Proceedings, Paper 1099, 2018. https://digitalcommons.unl.edu/tsaconf/1099

${ }^{16}$ Jane Wheeler, A.J.F. Russel and Hilary Redden, "Llamas and alpacas: Pre-conquest Breeds and Post-conquest Hybrids," Journal of Archaeological Science 22 (1995): 833-840.

17 Wheeler, Russel and Redden, "Llamas and alpacas," 838.

${ }^{18}$ Jane Wheeler, Lounès Chikhi, and Michael W. Bruford, "Genetic analysis of the origins of domestic South American camelids," in Documenting Domestication: New Genetic and Archaeological Paradigms, edited by Melinda Z. Zeder, Daniel G. Bradley, Eve Emshwiller and Bruce D. Smith, 329-341. Berkeley, Los Angeles and London: University of California Press, 2006.
} 
fine-fleeced llamas, it also serves to indicate the likely quality of the fleece that was available during the periods when Tiwanaku and Wari were dominant, especially for the production of high status garments. Tiwanaku spinners and weavers relied on camelid fibre yarns to loop four-corner hats and to weave tapestry tunics, mantles and bags. ${ }^{19}$ Wari spinners and weavers used cotton yarns for the warp and camelid fibres in the weft to weave tapestries for headgear, tunics, mantles and bags. ${ }^{20}$ They knotted four-cornered hats from camelid fibre yarns with a lustrous pile finish.
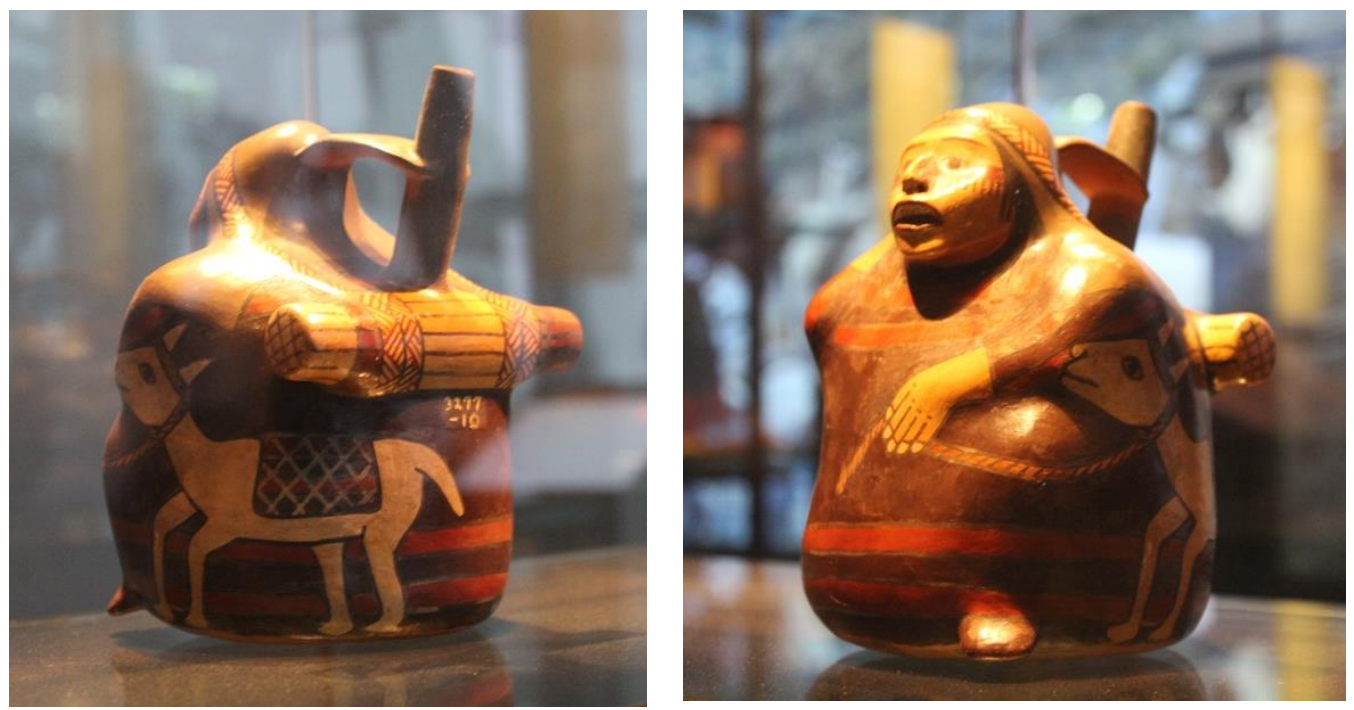

Figure 4. Polychrome Nasca effigy vessel. Museum voor Volkenkunde, Leiden RV-3277-10. Photograph @ P. Dransart

Pastures on the slopes of Nevado Ampato, from where the Sihuas river rises, is a candidate for being an area that saw an early rise in the occurrence of white fleeced camelids prior to Tiwanaku and Wari expansion. The panel in Figure 2 belongs to what Joerg Haeberli called Siguas Phase 1, dating from the end of the first millennium BC. Both the warp and the weft are discontinuous, and the use of the technique highlights the whiteness of the white against the darker surrounding colours during a period when it is likely to have been a scarce resource. Double-woven belts found in disturbed contexts from the site of La Real in the Majes valley have been assigned to Siguas Phase 3, dating from the Early Intermediate Period. ${ }^{21}$ These belts feature the use of white in motifs, making an interplay between the positive and negative use of white. There is an alternation between figure and ground and the white contrasts with the other colours constituting the design.

By about AD 500, it appears that all white camelids were already present in herds of llamas and alpacas (Figure 4). A Nasca effigy bottle shows a woman leading an all-white camelid, perhaps a llama. Because she has a bundle of firewood on her back, the llama probably is

\footnotetext{
${ }^{19}$ Margaret Young-Sanchez, "Tunic with Shoulder Panels," "Tapestry Tunic," and "Trapezoidal Tunic," in Margaret Young-Sánchez, ed., Tiwanaku, 41-52.

${ }^{20}$ Susan E. Bergh, "Tapestry-woven Tunics", in Wari: Lords of the Ancient Andes, edited by Susan E. Bergh, 158-191. New York: The Cleveland Museum of Art and Thames and Hudson, 2012.

${ }^{21}$ Gladys Cecilia Quequezana Lucano, Willy J. Yépez Álvarez and Marko Alfredo López Hurtado, "Técnicas textiles: vestidos e identidad colectiva", in ¿Wari en Arequipa? Análisis de los Contextos Funerarios de La Real, edited by Willy J. Yépez Álvarez and Justin Jennings, 98-127. Arequipa: Museo Arqueológico José María Morante, Universidad National de San Agustín de Arequipa, 2012. See figures 4.4a, 4.4b, 4.5, 4.17a, and $4.17 \mathrm{~b}$
} 
about to be sacrificed. The black outlining of the hands in the painting of the design has its counterpart in the black outlines that occur in Nasca textiles. The tapestry woven band in Figure 5 demonstrates the use of black outlining to surround guanaco- or vicuña-coloured camelids depicted in alternation with white camelids.

Black outlining is associated in particular with the so-called proliferous Nasca style, which is usually dated late in the Nasca sequence when applied to pottery. Joerg Haeberli described some unusual examples of this proliferous style in textiles. These tapestries have their own
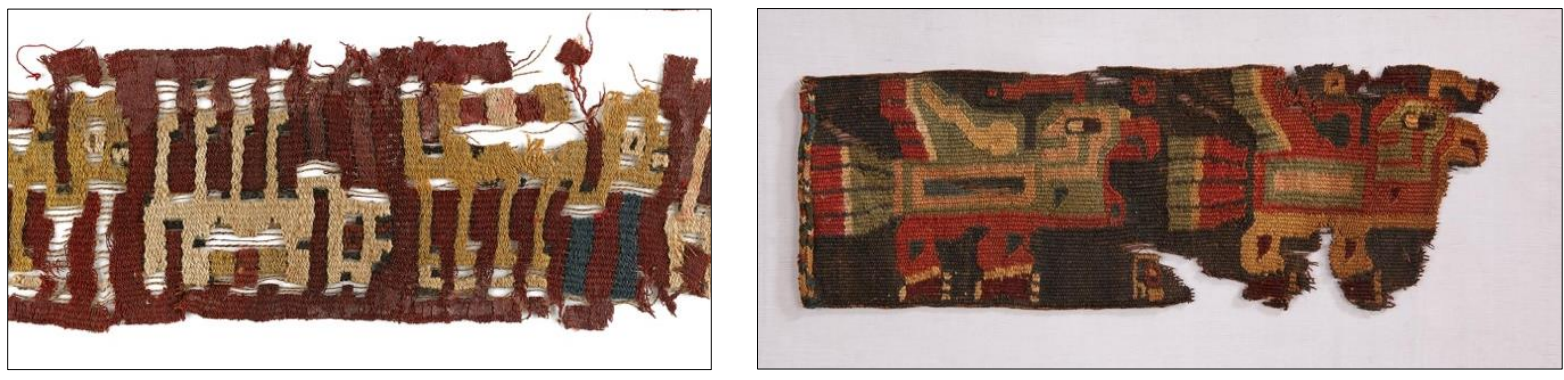

Figure 5 (Left). Nasca style woven band depicting guanaco- or vicuña-coloured camelids and white camelids in alternation. Camelid weft, bichrome warp, tapestry weave. Am1986,Q.252 Photograph @ British Museum www.britishmuseum.org

Figure 6 (Right). Early Tiwanaku style band. Interlocked tapestry with a cross-knit looped edging, camelid warp and weft. Gift of Mr. and Mrs. Herbert L. Lucas, Jr. X86-2913 Photograph @ Fowler Museum at UCLA www.fowler.ucla.edu

development early in the Nasca sequence, perhaps the equivalent of Nasca Phase 2 in comparison with the Nasca heartland, but they are thought to have come from valleys in the department of Arequipa. ${ }^{22}$ Haeberli reported a high incidence of camelid fibre in the warp, in contrast to tapestries from the Nasca heartland. In common with later Wari tapestries, Nasca ones usually have a cotton warp. ${ }^{23}$ In his analysis, the camelid fibre warp threads are often bichrome or trichrome, in shades of white, beige, and different browns.

Often the threads used for the black outlines in the Nasca tapestries are brittle or almost completely deteriorated, as in Figure $5 .^{24}$ This degradation is usually attributed to the corrosive effect of the mordant used to produce black dye. Such an explanation implies that weavers did not have sufficient black fleece for the outlining. Nathalie Boucherie and her colleagues detected a few cases of dyed black yarns in Nasca textiles. They suggested that some cotton yarns probably used an iron mordant, but the fiber content of another black yarn, dyed using indigo and a source of tannin, is not mentioned. ${ }^{25}$ Unlike all-white llamas and alpacas, which had already emerged during the Early Intermediate Period, black camelids perhaps remained scarce until the subsequent period of Tiwanaku and Wari domination.

Tiwanaku textiles make use of a sonorous colour palette, often with a dark tonality. A tunic found with burials in a cave at Pulacayo, east of the Salar de Uyuni in Bolivia, uses plain stripes of strong yellow between an interlocked tapestry-woven panel depicting staff-bearing figures in red, green-blue, yellow ochre and lighter yellow with accents of purplish red and

\footnotetext{
${ }^{22}$ Joerg Haeberli, "When and Where Did the Nasca Proliferous Style Emerge?" in Andean Archaeology III, edited by William H. Isbell and Helaine Silverman, 401-434. Boston, MA: Springer, 2006.

${ }^{23}$ Haeberli, "When and Where?" 428.

${ }^{24}$ Dransart, Earth, Water, Fleece and Fabric, 147-9; Haeberli, "When and Where?" figure 15.5.

${ }^{25}$ Boucherie, Nowik, and Cardon, "La producción tintórea Nasca."
} 
white on a dark blue ground..$^{26}$ These anthropomorphic figures have an upward curving nose, and they sport the snarling teeth of a feline. They derive from a tradition seen in stone carved architraves, including the Kantatayita lintel from Tiwanaku, which is dated, on stylistic grounds, prior to AD 400. William Conklin reconstructed the Kantatayita carving as having eight staff-bearing figures flying in profile towards each other. ${ }^{27}$ The two central figures have upward curving noses, like the figures in the later Pulacayo tunic. These figures are also related to the so-called Sun Gate at Tiwanaku, dated c. AD 550, in which a front faced personage with a rayed head is flanked by winged attendant figures, some having bird heads, others human heads. ${ }^{28}$ Green and red birds woven in a comparable, if reduced colour scheme, also appear in a fragmentary band in the Fowler Museum at UCLA (Figure 6). They resemble the birds in the upper and lower corners of the panel in Figure 3.

Rebecca Stone argues that repetition served as an important visual strategy in Tiwanaku iconography, and that its constituent elements had to be recognisable in textiles and other media along the far-reaching trade routes that Tiwanaku established throughout the SouthCentral Andes. ${ }^{29}$ Camelid headed figures with the posture of a running human being confront each other on an adult-sized tapestry tunic with dovetailed colour changes found in the grave of a child at Omo M10 in Moquegua. ${ }^{30}$

Flying or running attendants also occur in Wari textiles. Some examples of winged figures follow the imagery of the Katatayita lintel and the Sun Gate fairly closely, but many others are depicted in a highly abstract manner. In the hands of Wari weavers, the imagery of the figures tends to dissolve into abstraction. ${ }^{31}$ The viewer glimpses a wing or a split eye in a dazzle of colours and shapes. Rebecca Stone-Miller examined the colour anomalies in the repeat patterning of Wari tunics. ${ }^{32}$ She observed that intrusive elements are often blue or in the blue-green range of colours. Dyeing with indigo, she argued, can have unpredictable outcomes. The preciousness of blue, therefore, was used intentionally to disrupt the viewer's expectations. $^{33}$

Many more Wari tapestry tunics and fragments have survived than is the case with Tiwanaku tunics. While some of them display gorgeously rich hues, others are based on a palette combining undyed yarns with a restricted range of dyed colours. Motifs are often outlined in white. The tunic fragment in Figure 7 uses both black and white outlining. Colour fading makes it possible to observe the hidden natural brown fleece selected for the yarns in the red areas. Another fragment, cut from the same or a similar tunic, in the collections of the

\footnotetext{
${ }^{26}$ Jose Berenguer Rodríguez, Tiwanaku. Señores del lago sagrado. Santiago: Museo Chileno de Arte Precolombino 2000; Carolina Aguiero P., "Los textiles de Pulacayo y las relaciones entre Tiwanaku y San Pedro de Atacama," Boletín del Museo Chileno de Arte Precolombino 12(1) (2007): 85-98.

${ }^{27}$ William J. Conklin, "Tiahunaco and Huari: Architectural Comparisons and Interpretations," in Huari Adminstrative Structure: Prehistoric Monumental Architecture and State Government, edited by William J. Isbell and Gordon F. McEwan, 281-291. Washington, D.C.: Dumbarton Oaks Research Library and Collections, 1991.

${ }^{28}$ Young-Sánchez, ed., Tiwanaku, 37.

${ }^{29}$ Rebecca R. Stone, Art of the Andes from Chavín to Inca. London: Thames and Hudson, 2012: 143-144.

${ }^{30}$ Sarah I. Baitzel and Paul Goldstein, "More Than the Sum of its Parts: Dress and Social Identity in a Provincial Tiwanaku Child Burial," Journal of Anthropological Archaeology 35 (2014): 51-62.

${ }^{31}$ Bergh, "Tapestry-woven tunics," 181-184.

${ }^{32}$ Rebecca Stone-Miller, "Creative Abstractions: Middle Horizon Textiles in the Museum of Fine Arts, Boston," in To Weave for the Sun: Ancient Andean Textiles in the Museum of Fine Arts, Boston, by Rebecca StoneMiller, 34-42. London: Thames and Hudson.

${ }^{33}$ Stone-Miller, "Creative Abstractions," 40.
} 
Metropolitan Museum of Art, shows that although the overall condition of the piece suffered some deterioration before it reached the museum, the black yarns have not decomposed
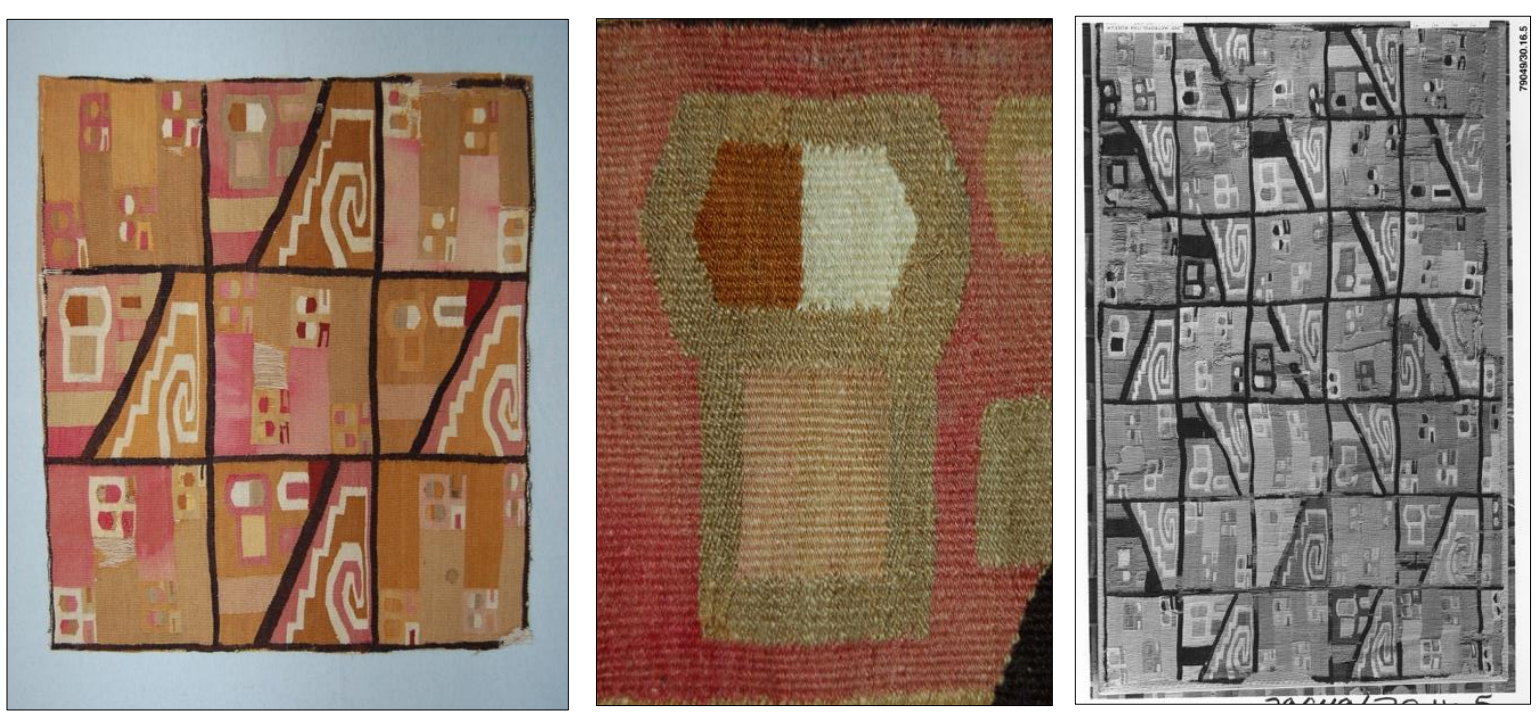

Figure $7 a$ and $7 b$ (Left and centre). Wari tunic fragment and detail showing profile face, step-fret and interlocked U-shaped motifs. Cotton warp and camelid weft, interlocked tapestry. Am1954,05.454. Photographs @ British Museum www.britishmuseum.org

Figure 8 (Right). Wari tapestry tunic fragment. Gift of George D. Pratt. 30.16.5. Photograph @ Metropolitan Museum of Art www.metmuseum.org

as in the Nasca tapestries with the black outlines (Figure 8). These yarns are likely to have been spun from the fleece of a black llama or alpaca.

Another difference between Tiwanaku and Wari textiles concerns how white fleece was exploited. An absolutely stunning version of a tunic with profile face and step-fret motifs in

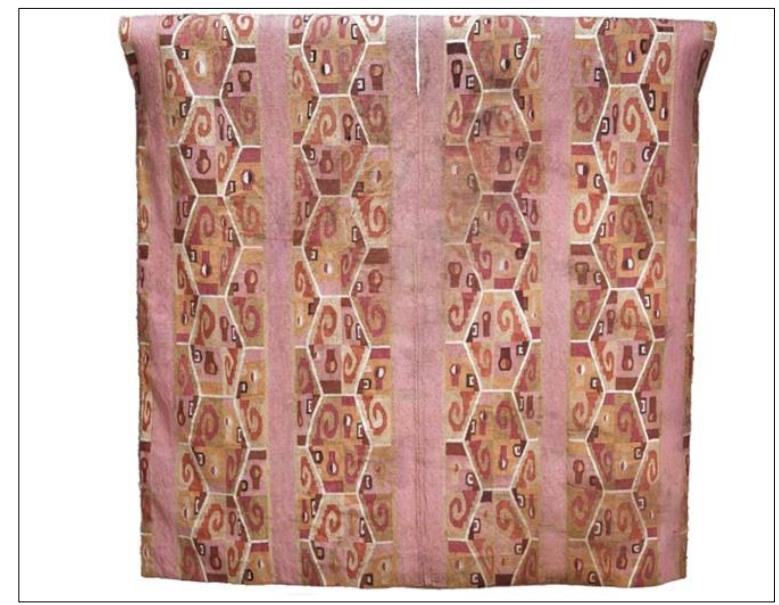

the Museo Chileno de Arte Precolombino demonstrates conspicuous use of white (Figure 9). ${ }^{34}$ In many run-of-the-mill Wari tunics, carmine-hued plain-weave stripes separate the brown fleece. In this case, however, the plain stripes are flamingo pink. These stripes are not

\footnotetext{
${ }^{34}$ Carole Sinclaire A., "Wari and Tiwanaku: Imperial Fabrics," in Awakhuni. Weaving the History of the Andes, edited by Carole A. Sinclaire, 52-63. Santiago: Museo Chileno de Arte Precolombino, 2007.
} 
Figure 9. Wari tapestry tunic. Camelid weft, tapestry weave. MCHAP 0947 Photograph @ Museo Chileno de Arte Precolombino https://museo.precolombino.cl

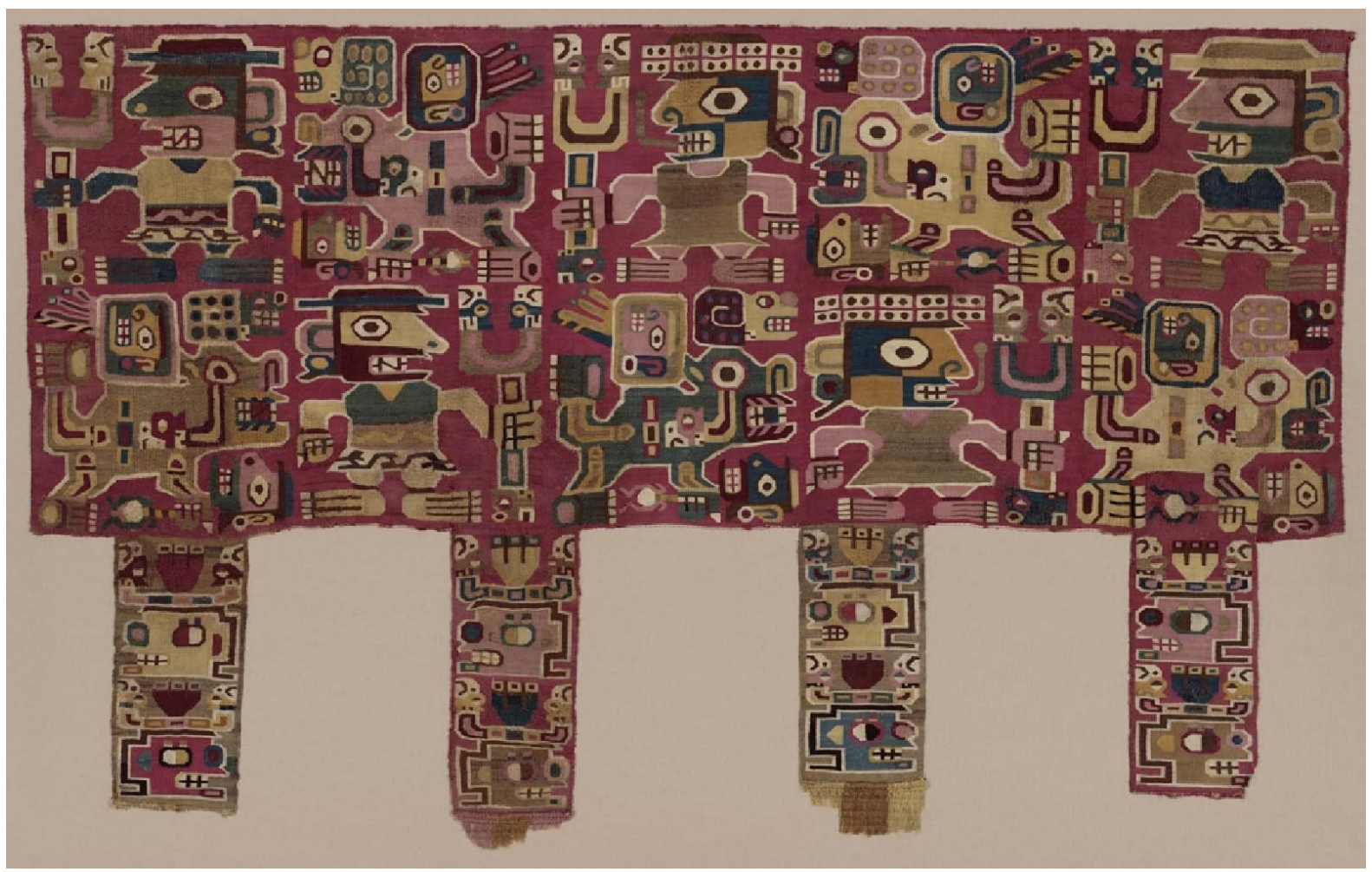

Figure 10. Wari panel. Cotton warp and camelid weft, interlocked tapestry. Charles Potter King Fund. 1996.50 Photograph (C) Museum of Fine Arts, Boston www.mfa.org

pale red as a second dye batch. They proclaim that the weavers had access to sufficient quantities of brilliant white fleece to achieve the flamingo colour and to complete the design.

A panel consisting of a wide band with four integral tabs incorporated along the lower edge provides another instance of the exploitation of Wari pink against a carmine red ground (Figure 10). This combination of colours recalls some of the headbands known from the coastal site of Huaca Malena. ${ }^{35}$

In addition to tapestry woven tunics, Wari weavers also produced tie-dyed tunics. ${ }^{36}$ To produce these scintillating textiles, it was necessary to prepare an all-white camelid warp and weft, woven in modular units, which were then resist-dyed and reassembled. ${ }^{37}$ The final

\footnotetext{
${ }^{35}$ Rommel Angeles Falcón, "Tocados del Horizonte Medio al Intermedio Tardío en la costa central: una vision desde el valle de Asia, Perú (siglos VII-XII d.C.)," in PreColumbian Textile Conference VII, edited by Lena Bjerregaard and Ann Peters, 277-307. Lincoln, Nebraska: Zea Books.

${ }^{36}$ Ann Pollard Rowe, "Tie-dyed tunics," in Wari: Lords of the Ancient Andes, edited by Susan E. Bergh, 192205. New York: Thames and Hudson, 2012.

${ }^{37}$ Penelope Dransart, "The Curious Case of Sir Henry Wellcome's Wooden Statuette Dressed in Tie-dyed Wari Cloth," in PreColumbian Textile Conference VII, edited by Lena Bjerregaard and Ann Peters, 259-276. Lincoln, Nebraska: Zea Books.
} 
result is an arrangement of dot-in-diamond shapes that characterise tie-dyeing as a technique and lines that recombine to make contrapuntal crosses and diamonds against the bold hues of
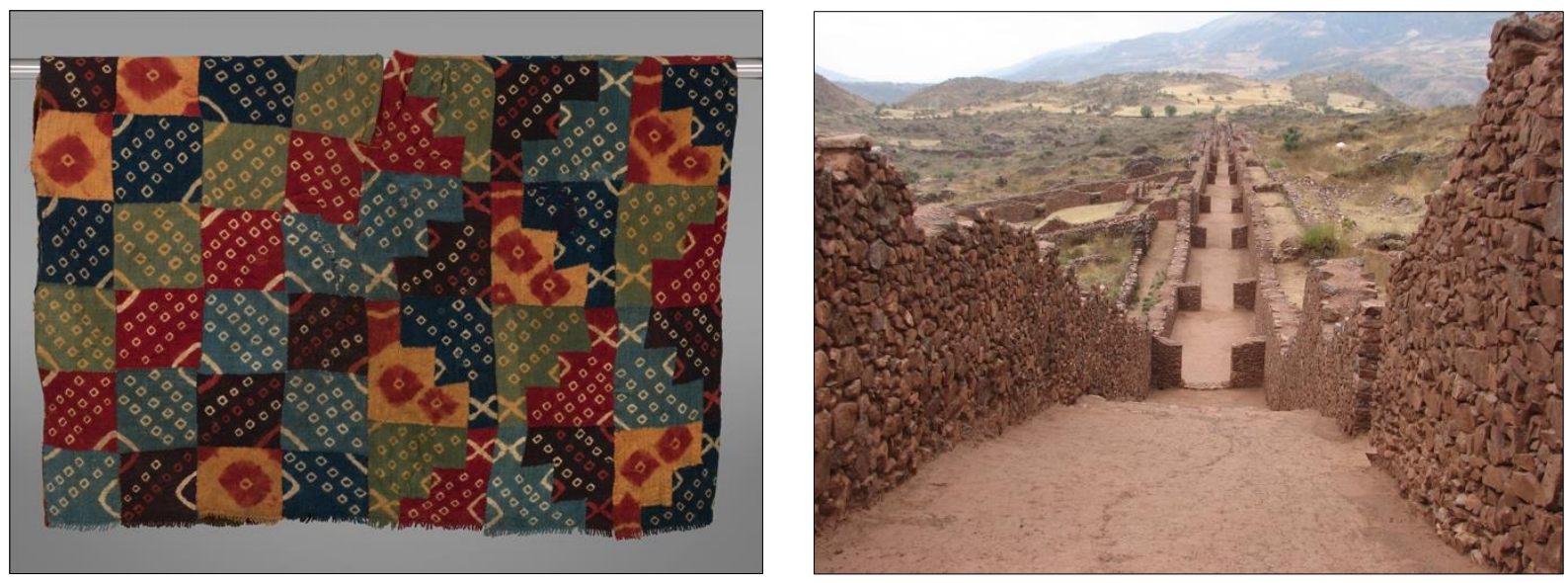

Figure 11 (Left). Wari style tie-dyed tunic, camelid fibre warp and weft. 1980.564.2, Metropolitan Museum of Art, gift of Arthur M. Bullowa. Photograph (C) Metropolitan Museum of Art www.metmuseum.org

Figure 12 (Right). A street at Pikillacta, a Wari provincial center near Cuzco, Peru. Photograph AgainErick, CC BY-SA 3.0, <https://creativecommons.org/licenses/by-sa/3.0>, via Wikimedia Commons

the dyed fabric (Figure 11). This hidden use of what must have been highly prized white fleece underscores the elite character of these textiles. No Wari style tie-dyed textiles have been reported from the Wari capital in the highlands of Ayacucho, where the environmental conditions are unfavourable for the preservation of organic remains. It is likely, however, that some of them were woven and dyed in the valleys that connect the highlands with the coast in the southern Peruvian departments of Ica and Arequipa, precisely the area in which the earlier Siguas textile tradition emerged.

Remarkable ceramic polychrome depictions of camelids bear witness to Wari people's appreciation for the different qualities of fleece. Large and small effigies of complete camelids and camelid heads were found in deposits of smashed offerings found at the site of Pacheco, in the Nazca region of southern coastal Peru. ${ }^{38}$ Some of these pottery vessels have been reconstructed. A standing llama or alpaca is painted to show the upper body in black with white face, belly, and inside the legs. ${ }^{39}$ Another camelid in the same standing posture has a cinnamon-coloured upper face and back, with white round the mouth, down the chest and inside the legs, perhaps to convey the coat of a vicuña. These camelids have a strong visual presence and individual details indicate their sex. ${ }^{40}$

In Wari society, men wore the tunics that have been discussed here. It seems, however, that many of the weavers were probably women. ${ }^{41}$ Although it was often hidden under chromatically bright dyed hues, the lustre of white fleece played a particular role when worn

\footnotetext{
${ }^{38}$ Mary Glowacki, "Shattered Ceramics and Offerings," in Wari: Lords of the Ancient Andes, edited by Susan E. Bergh, 144-157. New York: Thames and Hudson, 2012.

${ }^{39}$ Glowacki, "Shattered Ceramics," 150.

${ }^{40}$ Glowacki, "Shattered Ceramics", 147.

${ }^{41}$ Wieslaw Wieckowski, Wari Women from Huarmey: Biological Interpretation of Human Remains from the Wari Elite Mausoleum at Castillo de Huarmey, Peru. Oxford: Archaeopress Pre-Columbian Archaeology 11, 2019.
} 
in the southern areas of Wari influence. Gordon McEwan and Patrick Ryan Williams describe the ceremonial site of Pikillacta, in the Lucre basin near Cuzco, as the abode of ancestors and the theatrical setting for rituals and feasts (Figure 12). ${ }^{42}$ They commented that its white plaster coating must have made it a "shining beacon on the landscape". Once inside the complex, the visitor would have been led through narrow passages with high walls; "only the sky above and the path ahead were visible". ${ }^{43}$ This setting would have provided the context for the officials who populated the compounds, dressed in dazzling garments, the brilliance of which depended on camelid fiber to achieve the desired effect.

Tiwanaku and Wari, as two different but related textile traditions, exploited the colours and other qualities of fibres differently in their fabrics and textiles. Tiwanaku tapestries tend to have a very dark ground against which reds, blues, and blue-greens resonate. There are jewellike accents of yellow and other pale hues. The use of a dark ground also features in some Wari tapestries. In a significant number of Wari textiles, however, white fleece was prized for its brilliance as well as for the affordances it gave to dyers to expand colour ranges in yellow and pink. This white fleece is not always immediately obvious because it hides underneath dyed hues.

Market-led desires to increase white or even-coloured fleece have prompted recent research efforts into the genetic mechanisms for llama and alpaca fleece traits. ${ }^{44}$ This article demonstrates that the desire to increase the production of white fleece is not only a modern concern. Fleece colours in alpacas and llamas are the outcome of herding practices by innumerable generations of herders. Wari textile workers used white fleece to produce flamingo pink, which, like millennial pink, became a cultural signifier.

\section{Acknowledgements}

I wish to thank Elena Phipps for encouraging me to present the paper on which this article is based at the Textile Society of America Symposium. I also appreciate the assistance offered by Pilar Alliende of the Museo Chileno de Arte Precolombino, Merel van Heesewijk of the Museum Volkenkunde, Leiden, and Jane K. Hutchins. Any errors or infelicities are my responsibility.

\section{References cited}

Agüero P., Carolina. "Los textiles de Pulacayo y las relaciones entre Tiwanaku y San Pedro de Atacama." Boletín del Museo Chileno de Arte Precolombino 12(1) (2007): 85-98.

Angeles Falcón, Rommel. “Tocados del Horizonte Medio al Intermedio Tardío en la costa central: una visión desde el valle de Asia, Perú (siglos VII-XII d.C.).” In PreColumbian

\footnotetext{
42 Gordon McEwan and Patrick Ryan Williams, "The Wari Built Environment: Landscape and Architecture of Empire," in Wari: Lords of the Ancient Andes, edited by Susan E. Bergh, 64-81. New York: Thames and Hudson, 2012.

${ }^{43}$ McEwan and Williams, "Wari Built Environment," 79.

${ }^{44}$ E.N. Frank, M.V.H. Hick, C.D. Gauna, H.E. Lamas, C. Renieri, and M. Antonini, "Phenotypic and Genetic Description of Fibre Traits in South American Domestic Camelids (Llamas and Alpacas)," Small Ruminant Research 61 (2006): 113-129.
} 
Textile Conference VII, edited by Lena Bjerregaard and Ann Peters, 277-307. Lincoln, Nebraska: Zea Books. http://digitalcommons.unl.edu/pct7/20

Baitzel, Sarah I. and Goldstein, Paul. "More Than the Sum of its Parts: Dress and Social Identity in a Provincial Tiwanaku Child Burial." Journal of Anthropological Archaeology 35 (2014): 51-62.

Berenguer Rodríguez, José. Tiwanaku. Señores del lago sagrado. Santiago: Museo Chileno de Arte Precolombino, 2000.

Bergh, Susan E. (ed.). Wari: Lords of the Ancient Andes, New York: The Cleveland Museum of Art and Thames and Hudson, 2012.

------, “Tapestry-woven Tunics", in Wari: Lords of the Ancient Andes, edited by Susan E. Bergh, 158-191.

Boucherie, Nathalie, Nowik, Witold and Cardon, Dominique. "La producción tintórea Nasca: nuevos datos analíticos obtenidos sobre textiles recientemente descubiertos en excavaciones." Nuevo Mundo Mundos Nuevos Colloques, 2016. http://journals.openedition.org/nuevomundo/69222

Conklin, William J. "Tiahunaco and Huari: Architectural Comparisons and Interpretations." In Huari Adminstrative Structure: Prehistoric Monumental Architecture and State Government, edited by William J. Isbell and Gordon F. McEwan, 281-291. Washington, D.C.: Dumbarton Oaks Research Library and Collections, 1991.

Dransart, Penelope. Earth, Water, Fleece and Fabric: An Ethnography and Archaeology of Andean Camelid Herding. London: Routledge, 2002.

"The Curious Case of Sir Henry Wellcome's Wooden Statuette Dressed in Tie-dyed Wari Cloth." In PreColumbian Textile Conference VII, edited by Lena Bjerregaard and Ann Peters, 259-276. Lincoln, Nebraska: Zea Books, 2017. http://digitalcommons.unl.edu/pct7/16

Frank, E.N., Hick, M.V.H., Gauna, C.D., Lamas, H.E., Renieri, C., and Antonini, M. "Phenotypic and Genetic Description of Fibre Traits in South American Domestic Camelids (Llamas and Alpacas).” Small Ruminant Research 61 (2006): 113-129.

Glowacki, Mary. "Shattered Ceramics and Offerings," in Wari: Lords of the Ancient Andes, edited by Susan E. Bergh, 144-157.

Haeberli, Joerg. "Siguas 1: a newly identified Early Horizon culture, Department of Arequipa, Peru.” Textile Society of America Symposium Proceedings, Paper 392, 2002. http://digitalcommons.unl.edu/tsaconf/392

------ "When and Where Did the Nasca Proliferous Style Emerge?" In Andean Archaeology III, edited by William H. Isbell and Helaine Silverman, 401-434. Boston, MA: Springer, 2006. 
McEwan, Gordon and Williams, Patrick Ryan. "The Wari Built Environment: Landscape and Architecture of Empire," in Wari: Lords of the Ancient Andes, edited by Susan E. Bergh, 64-81.

Mengoni Goñalons, Guillermo L., and Yacobaccio, Hugo D. "The Domestication of South American Camelids: A View from the South-Central Andes." In Documenting Domestication: New Genetic and Archaeological Paradigms, edited by Melinda Z. Zeder, Daniel G. Bradley, Eve Emshwiller, and Bruce D. Smith, 228-244. Berkeley: University of California Press, 2006.

Niemeyer, Hermann N. and Agüero, Carolina. "Dyes Used in Pre-Hispanic Textiles from the Middle and Late Intermediate Periods of San Pedro de Atacama (Northern Chile): New Insights into Patterns of Exchange and Mobility." Journal of Archaeological Science 57 (2015): 14-23.

Quequezana Lucano, Gladys Cecilia, Yépez Álvarez, Willy J., and López Hurtado, Marko Alfredo. "Técnicas textiles: vestidos e identidad colectiva,” in ¿Wari en Arequipa? Análisis de los Contextos Funerarios de La Real, edited by Willy J. Yépez Álvarez y Justin Jennings, 98-127. Arequipa: Museo Arqueológico José María Morante, Universidad National de San Agustín de Arequipa, 2012.

Rosoff, Nancy B. "The Rayed Head and Stepped Platform: A Core Symbol of the Southern Andean Iconographic Series." Textile Society of America Symposium Proceedings, Paper 1099, 2018. https://digitalcommons.unl.edu/tsaconf/1099

Rowe, Ann Pollard "Tie-dyed tunics." In Wari: Lords of the Ancient Andes, edited by Susan E. Bergh, 192-205.

Sinclaire A., Carole, "Wari and Tiwanaku: Imperial Fabrics," in Awakhuni. Weaving the History of the Andes, edited by Carole A. Sinclaire, 52-63. Santiago: Museo Chileno de Arte Precolombino, 2007.

Splitstoser, Jeffrey C., Tom D. Dillehay, Jan Wouters, and Ana Claro. "Early Pre-Hispanic Use of Indigo Blue in Peru." Science Advances 2.9 (2016): e1501623.

Stone-Miller, Rebecca. "Creative Abstractions: Middle Horizon Textiles in the Museum of Fine Arts, Boston." In To Weave for the Sun: Ancient Andean Textiles in the Museum of Fine Arts, Boston, by Rebecca Stone-Miller, 34-42. London: Thames and Hudson.

Stone, Rebecca. Art of the Andes from Chavín to Inca. London: Thames and Hudson, 2012.

Wheeler, Jane C. "On the Origin and Early Development of Camelid Pastoralism in the Andes." In Animals and Archaeology: 3 Early Herders and Their Flocks, edited by J. Clutton-Brock and C. Grigson, 395-410. Oxford: BAR International Series 202, 1984.

Wheeler, Jane C., Lounès Chikhi, and Michael W. Bruford. "Genetic analysis of the origins of domestic South American camelids." In Documenting Domestication: New Genetic and Archaeological Paradigms, edited by Melinda Z. Zeder, Daniel G. Bradley, Eve Emshwiller and Bruce D. Smith, 329-341. Berkeley, Los Angeles and London: University of California Press, 2006. 
Wheeler, Jane C., and Laker, Jerry. "The Vicuña in the Andean Altiplano," The Vicuña: The Theory and Practice of Community-Based Wildlife Management, edited by Iain J. Gordon, 21-33. New York: Springer, 2009.

Wheeler, Jane, Russel, A.J.F., and Redden, Hilary. "Llamas and Alpacas: Pre-conquest Breeds and Post-conquest Hybrids," Journal of Archaeological Science 22 (1995): 833840.

Wieckowski, Wieslaw. Wari Women from Huarmey: Biological Interpretation of Human Remains from the Wari Elite Mausoleum at Castillo de Huarmey, Peru. Oxford: Archaeopress Pre-Columbian Archaeology 11, 2019.

Wouters, J., and N. Rosario-Chirinos. "Dye Analysis of Pre-Columbian Peruvian Textiles with High-Performance Liquid Chromatography and Diode-Array Detection." Journal of the American Institute for Conservation 31(2) (1992): 237-255.

Young-Sánchez, Margaret (ed.). Tiwanaku: Ancestors of the Inka, Lincoln, Nebraska: Denver Art Museum and University of Nebraska Press, 2004. 